\title{
Immune Complexes in Congenital and Natal Cytomegalovirus Infections of Man
}

\author{
Sergio Stagno, John E. Volanakis, David W. Reynolds, Robert Stroud, \\ and Charles A. AlFord, Departments of Pediatrics, Medicine, and \\ Microbiology, Medical School, University of Alabama in Birmingham \\ 35294
}

\begin{abstract}
A B S T RAC T The occurrence of circulating immune complexes was investigated in 31 patients with cytomegalovirus infection (29 infected in utero and 2 with natal infection) and 34 uninfected controls. Anticomplementary activity above 1:20 occurred in $34 \%$ $(29 / 86)$ of the sera tested from the infected group in contrast to $7.5 \%(3 / 40)$ in the controls $(P<0.005)$. When assayed by means of a lymphoblastoid cell line (Raji cell test), the reactivity in these groups was $45(39 / 86)$ and $2.7 \%(1 / 36)$, respectively $(P<0.001)$. Correlation of results between these two complement-dependent assays occurred in $75 \%$ of samples collected from the infected group. Frequency of reactivity was higher in severe intrauterine infection and during the lst yr of life paralleling the patterns of viral excretion and humoral immune responses. Physicochemical characterization demonstrated that reactive substances in sera were acid-dissociable and, in one sample tested, contained 7S IgG antibodies with cytomegalovirus (CMV) specificity. Circulating immune complexes were heavier (18-22S) in sick, as opposed to subclinically CMV-infected patients, in whom intermediate size complexes (12-16S) were found. In three of four symptomatic patients whose demise was due to severe congenital infection, granular deposits of immunoglobulins and C3 were detected in a pattern typical of immune complexes along the glomerular basal membrane of the glomeruli. Whether or not circulation and deposition of heavier immune complexes contributed to the adverse clinical outcome is unresolved. Because of the high incidence of both congenital and natal CMV infections, definition of the pathogenetic potentials of both heavy and intermediate size immune complexes is required to design more effective therapeutic measures.
\end{abstract}

Received for publication 28 February 1977 and in revised form 16 May 1977.

\section{INTRODUCTION}

Cytomegaloviruses (CMV) ${ }^{1}$ are the leading cause of congenital infections of man with rates ranging from 0.5 to $2.4 \%$ of all live-births (1-3). CMV may also be acquired by an additional 3-5\% of neonates and young infants via exposure to maternal genital tract secretions, breast milk, and household contacts (4). Fortunately, disease is rare with intrauterine infection and virtually lacking with natal or early postnatal acquisitions. Overt disease, with prominent involvement of reticuloendothelium, brain, and perceptual organs leading inevitably to debilitating sequelae, occurs in $<5 \%$ of infants infected in utero. However, as recently shown, significant numbers of the remaining $95 \%$ subclinically infected at birth, manifest late-appearing injury, namely sensorineural hearing defects and decreased mentation (reviewed in reference 5). Perhaps this should not be surprising because CMV, when prenatally acquired, produces a chronic infection lasting several years. Persistent viral replication occurs in salivary gland and renal parenchyma as demonstrated by excretion of infectious virus in urine and saliva (6). Likely viral replication also persists in other sites inaccessible to routine virologic examination. Congenital CMV infection, is also characterized by an apparent overstimulation of the humoral immune system as exemplified by accelerated postnatal development of serum IgM and IgG as compared to uninfected controls (7). Though immunoglobulin development only grossly gauges antigenic load, it provides an indirect means for estimating the magnitude of the persistent antigenic stimulation associated with prenatally acquired CMV infection. More importantly, the specific humoral immune responses elicited are substantial

\footnotetext{
${ }^{1}$ Abbreviations used in this paper: AC, anticomplementary; CMV, cytomegalovirus; FITC, fluorescein isothiocyanate; IF, immunofluorescence, $-t$.
} 
and prolonged, whether the infection is productive or latent. (6)

The persistence of viral excretion in the face of an overstimulated host immune responses provides a setting in which immune complex formation is highly probable. In fact, preliminary evidence suggests their occurrence in congenital and natal CMV infections $(8,9)$. Defining the formation of immune complexes and their relative amounts, size, and physiochemical nature is important in assessing their possible role in the pathogenesis of disease, both acute and long term, especially with the intrauterine form of CMV infection.

In the present study, circulating immune complexes of intermediate size were encountered in patients with subclinical congenital CMV infection. In contrast, symptomatic patients circulated immune complexes of higher molecular size, and in three patients who died with severe disease deposits of IgG, IgM and C3 were demonstrated in the basal membrane of the glomeruli.

\section{METHODS}

Patients. We studied 31 patients with $\mathrm{CMV}$ infection and 34 uninfected controls. 29 were infected in utero, and 2 had natal CMV infection acquired via exposure to an infected maternal birth canal. Specific diagnosis was established as previously described (6). Eight congenitally infected patients were symptomatic at birth, their main clinical manifestations being hepatosplenomegaly, jaundice, and thrombocytopenia. As a consequence of the severity of the infection, four of these patients died, three during the first 2 wk of life and the fourth at 8 mo of age. The remaining 23, including the 2 with natally acquired CMV, had a subclinical infection at birth.

Sera. From CMV-infected patients, 109 sera were collected at preselected intervals from birth up to $8 \mathrm{yr}$. 56 samples were obtained during the 1st yr of life. From the control group, 48 samples were available, 41 of which were also collected during the 1st yr after delivery. All sera tested had been stored at $-20^{\circ} \mathrm{C}$ for varying periods ranging from 1 to $7 \mathrm{yr}$, the great majority for $<1-2$ yr.

Anticomplementary activity test. Sera were assayed for their ability to consume in vitro total hemolytic complement by a modification of the microcomplement fixation method of Wasserman and Levine (10). Before testing, sera were heatinactivated at $56^{\circ} \mathrm{C}$ for $30 \mathrm{~min}$. Veronal-buffered saline containing $0.15 \mathrm{mM} \mathrm{Ca}++, 1.0 \mathrm{mM} \mathrm{Mg}++$, and $0.1 \%$ gelatin, ionic strength $0.147, \mathrm{pH} 7.3$, was used throughout. For initial screening purposes, $0.5 \mathrm{ml}$ of a 1:10 dilution of each serum was incubated overnight at $4^{\circ} \mathrm{C}$ with 1.2-1.5 $\mathrm{CH}_{50} \mathrm{U}$ of human complement $(0.5 \mathrm{ml})$. Optimally sensitized sheep erythrocytes $\left(2.5 \times 10^{7}\right.$ in $\left.0.5 \mathrm{ml}\right)$ were then added, and the samples were incubated for $90 \mathrm{~min}$ at $37^{\circ} \mathrm{C} .2 \mathrm{ml}$ of normal saline was then added, and after centrifugation the percent lysis was calculated spectrophotometrically $(410 \mathrm{~nm})$ from the amount of hemoglobin released in the supernate. Anticomplementary activity of positive sera was subsequently quantitated. The reciprocal of the dilution resulting in consumption of half of the available complement was judged as the end point in titrations.

Raji cell test. This assay was performed as described by Theofilopoulos et al. (11). The Raji cells were grown as continuous cell lines in RPMI 1640 medium with $20 \%$ fetal calf serum. Cell viability was determined by trypan blue exclu- sion. The Raji cell Fc receptors were first blocked by incubating $5 \times 10^{6}$ cells with $1 \mathrm{mg}$ of human $\mathrm{IgG}$ at $37^{\circ} \mathrm{C}$ for $20 \mathrm{~min}$. IgG was obtained from Cohn fraction II after fractionation on a DEAE-52 cellulose column equilibrated with $0.01 \mathrm{M}$ phosphate buffer, pH 7.3 (aggregates were removed by centrifugation at $150,000 \mathrm{~g}$ for $90 \mathrm{~min}$ ). After two washes with minimum essential medium the cells were reacted with $50 \mu$ l of Fab' anti-human IgG (Hyland Div., Travenol Laboratories, Inc., Costa Mesa, Calif.) at $4^{\circ} \mathrm{C}$ for $30 \mathrm{~min}$ to block the $7 \mathrm{~S} \mathrm{IgG}$ bound to the Fc receptors. Subsequently, cells were washed twice in minimum essential medium and incubated for $30 \mathrm{~min}$ at $4^{\circ} \mathrm{C}$ with $50 \mu \mathrm{l}$ of test sera. Finally, cells were again washed twice with minimum essential medium and incubated for 30 min at $4^{\circ} \mathrm{C}$ with $25 \mu \mathrm{l}$ of a 1:20 dilution of fluorescein isothiocyanate (FITC) goat anti-human Fc-IgG (fluorescein to protein ratio of 3 , protein concentration of $1 \mathrm{mg} / \mathrm{ml}$ ). After two washes in minimum essential medium, cells were resuspended in $20 \mu \mathrm{l}$, smeared on glass slides, and observed by microscope for fluorescence. The degree of fluorescence was graded semiquantitatively from negative to $3+$ based on the presence of large, irregular fluorescent granules on the surface of viable cells.

Sucrose density ultracentrifugation. Linear sucrose density gradients were prepared either in Veronal-buffered saline, $\mathrm{pH} 7.3$, or in acetate buffer, $\mathrm{pH}$ 4.0. Centrifugation proceeded for $18 \mathrm{~h}$ at $35,000 \mathrm{rpm}$ at $4^{\circ} \mathrm{C}$ in a Beckman model L ultracentrifuge (Beckman Instruments, Inc., Spinco Div., Palo Alto, Calif.) with a swinging SW $50 \mathrm{~L}$ rotor. $0.2 \mathrm{ml}$ of sera was layered over the gradients equilibrated to $4^{\circ} \mathrm{C} .0 .2 \mathrm{ml}$-serial fractions were collected from the top of the 4-ml gradients by means of an ISCO fractionator (model 640, Instrumentation Specialties Co., Inc., Lincoln, Neb.). Human albumin, IgG, and IgM quantitated by radial immunodiffusion on the fractions obtained from a control normal human serum included in each run served as the $5 \mathrm{~S}, 7 \mathrm{~S}$, and $19 \mathrm{~S}$ markers, respectively.

Gel filtration. Gel filtration was performed by layering $2 \mathrm{ml}$ of serum on a $0.7 \times 100.0-\mathrm{cm}$ Sephadex G-200 column (Pharmacia Fine Chemicals, Div. of Pharmacia Inc., Piscataway, N. J.) equilibrated with $0.1 \mathrm{M}$ Tris- $\mathrm{HCl}, 0.2 \mathrm{M} \mathrm{NaCl}$ buffer, pH 8.0. 2-ml fractions were collected. Protein concentrations were determined by the Folin-Ciocalteu method (12).

Immunofluorescent (IF) antibody test. CMV-specific antibodies present in sera or fractions were determined by the indirect IF assay for the late antigens of CMV (AD-169 strain), as previously described (6). A 1:100 dilution of a FITC-conjugated goat anti-human Fc-IgG (fluorescein to protein ratio of 3 and a protein concentration of $1 \mathrm{mg} / \mathrm{ml}$ ) prepared in this laboratory was employed. Before testing, all fractions that were collected from the acetate buffer $\mathrm{pH}$ 4.0 gradients were neutralized to $\mathrm{pH} 7.2$ with $2 \mathrm{M}$ Tris buffer. The feasibility of antibody measurements on these fractions by the IF method was demonstrated when the antibody levels of two positive control sera were shown to be similar before and after an $18-\mathrm{h}$ incubation at $4^{\circ} \mathrm{C}$ in a $1: 4$ dilution of acetate buffer, $\mathrm{pH}$ 4.0.

Immunoglobulin quantification and immunoelectrophoresis. Levels of IgG and IgM used as sedimentation markers were determined by radial immunodiffusion (13). Immunoelectrophoresis was performed in $0.5 \%$ agarose in $0.05 \mathrm{M}$ Veronal buffer, pH 8.2 (14).

Immunohistopathology. From three patients with fatal infection, portions of kidney tissue obtained at autopsy were prepared by fixation in $95 \%$ cold ethanol followed by paraffin embedding according to the method of SainteMarie (15) and by snap freezing at $-70^{\circ} \mathrm{C}$ in O.C.T. compound (Ames Lab-Tek Products, Div. of Miles Laboratories, Elkhart, Ind.) (16). To detect deposition of immune com- 
plexes, $4-\mu \mathrm{m}$ thin sections of renal tissue were cut in a cryostat, air dried, fixed in acetone for $10 \mathrm{~min}$, and stained with fluorescent antisera to human IgG, IgM, and C3/C3c. Antisera to IgG and IgM were raised in goats. The purification, separation of Ig fractions, and conjugation with FITC was performed at this institution (17). Anti-C3/C3c antiserum (fluorescein to protein ratio of 2.7 , protein concentration of $3.4 \mathrm{mg} / \mathrm{ml}$ ) was obtained commercially (Hyland Div., Travenol Laboratories, Inc.).

To detect the presence of CMV antigens in the glomerular basal membrane deposits, $4-\mu \mathrm{m}$ thin sections of paraffinembedded kidney tissue were tested by indirect IF before and after elution procedures which consisted of a 30-min pretreatment with $2 \mathrm{M} \mathrm{NaCl}$ or $\mathrm{pH} 2.4$ glycine buffer (18). A human serum obtained from a 12-mo-old infant with subclinical CMV infection provided the source of antibody. This serum had a CMV titer of 1:1,024 and lacked antibodies to Epstein-Barr (19) and varicella-zoster (20) by indirect IF.

The distribution of CMV antigens in the renal parenchyma was also sought out by anticomplementary immunofluorescence (ACIF) according to the method of Reedman and Klein (21). Briefly, tissue sections mounted on glass slides were first incubated with the human serum that provided our source of anti-CMV antibodies. After heat inactivation $\left(56^{\circ} \mathrm{C}, 30 \mathrm{~min}\right)$ this serum had a $1: 256$ titer of complement-fixing antibodies to $\mathrm{CMV}$ as determined by the serologic ACIF assay. After incubation for $1 \mathrm{~h}$ at $37^{\circ} \mathrm{C}$, followed by thorough washing in phosphate-buffered saline, tissue sections were incubated for a similar period with a $1: 10$ dilution of fresh normal human serum lacking antibodies to CMV, varicella-zoster (20), and Epstein-Barr (19) viruses which provided the source of complement. The binding of C3 to the specific antigen-antibody complexes which locate in the infected cells was sought out with FITCconjugated goat anti-human $\mathrm{C} 3 / \mathrm{C} 3 \mathrm{c}$ at a dilution of 1:30. Controls of specificity for this procedure included incubation of tissue sections with serum lacking CMV antibodies, heat inactivation of the complement source, blocking with unconjugated anti-C3/C3c antibody, and the use of tissue sections of kidneys obtained from uninfected infants who died of unrelated causes.

\section{RESULTS}

Anticomplementary activity. As shown in Fig. 1, levels of anticomplementary (AC) activity above 1:20 were detected in 29 of 86 sera $(34 \%)$ collected from the CMV-infected infants as opposed to 3 of 40 sera $(7.5 \%)$ obtained from the uninfected controls $(P<0.005)$. More importantly, 14 of the 18 infected patients tested had at least one sample with elevated AC levels in contrast to only 3 of the 26 uninfected controls $(P<0.001)$. Increased AC activity in the infected group was primarily detectable in sera collected during the lst yr after delivery with 20 of 40 samples having levels of $1: 20$ or greater compared to 9 of 46 for those obtained afterwards $(P<0.001)$.

Raji cell test. 86 sera from the CMV-infected group were examined by this method. $1-3+$ positive results were obtained in 39 samples $(45 \%)$. In contrast, only 1 of $36(2.7 \%)$ samples obtained from the uninfected controls were reactive $(P<0.001)$. 18 of $27(66 \%)$ sera obtained from the eight symptomatic patients were found positive as opposed to 21 of 59 (35\%) sera collected from subjects with subclinical infection $(P<0.02)$. Like AC activity, Raji cell reactivity was age-related. $66 \%(29 / 44)$ of the sera collected during the 1st yr after delivery were positive whereas only $28 \%$ of sera obtained at later ages were reactive. Among symptomatic infected patients, positive results were obtained on 13 of 16 and 5 of 11 sera collected before and after $1 \mathrm{yr}$ of age, respectively. With subclinical infection comparable results were found with 15 of 28 and 6 of 31 sera, respectively. Data relating AC activity and Raji cell positivity in infected and control groups are shown in Table I. Concordance between assays was $75 \%$ using sera from the infected group and $90 \%$ with control samples. Despite this strong correlation, Raji cell test results were positive on 10 sera from the infected group when insignificant (titer $<1: 20$ ) AC activity was detected and negative on six sera with elevated titers $(>1: 20)$.

Physicochemical characterization of circulating immune complexes. From infants with subclinical congenital CMV infection, two sera reactive in the Raji cell test with AC titers of $1: 68$ and 1:76 were examined by ultracentrifugal analyses in neutral (pH 7.3) and acid (pH 4.0) gradients. Results from the examination of one of these sera are summarized in Fig. 2. After fractionation at neutral $\mathbf{p H}, \mathbf{A C}$ and Raji cell reactivities were present in fractions corresponding to the $12-16 \mathrm{~S}$ area of the gradients. However, both reactions disappeared or were markedly diminished after ultracentrifugation in acid gradients.

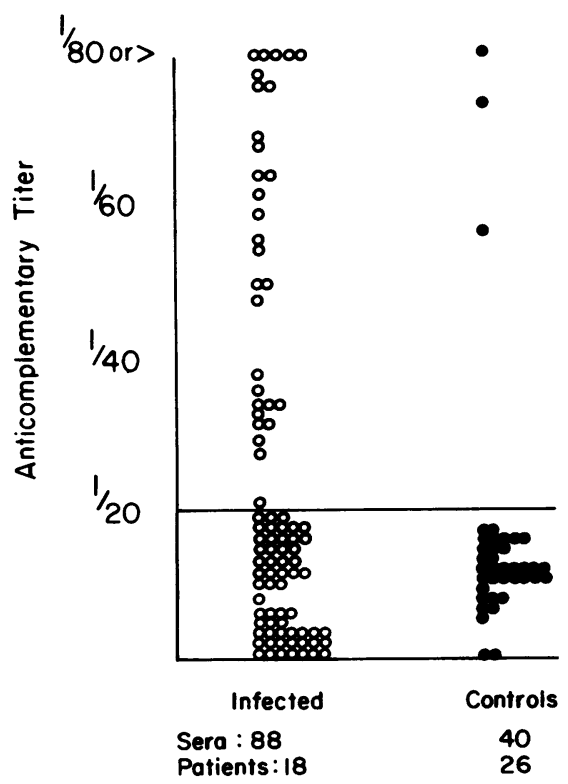

FIGURE 1 Levels of AC activity in sera of patients with congenital or natal $\mathrm{CMV}$ infection $(O)$ and uninfected controls (O). 
TABLE I

Correlation between Raji Cell Test and Level of AC Activity

\begin{tabular}{|c|c|c|c|c|c|c|}
\hline & \multicolumn{3}{|c|}{ CMV infected } & \multicolumn{3}{|c|}{ Uninfected controls } \\
\hline & \multicolumn{2}{|c|}{ Raji cell test } & \multirow[b]{2}{*}{ Total } & \multicolumn{2}{|c|}{ Raji cell test } & \multirow[b]{2}{*}{ Total } \\
\hline & Positive & Negative & & Positive & Negative & \\
\hline \multirow{3}{*}{$\begin{array}{l}\text { AC level above 1:20 } \\
\text { AC level below 1:20 }\end{array}$} & 15 & 6 & 21 & 0 & 2 & 2 \\
\hline & 10 & 33 & 43 & 0 & 18 & 18 \\
\hline & 25 & 39 & 64 & 0 & 30 & 20 \\
\hline
\end{tabular}

As noted in Fig. 2, comparative analyses of the distribution of specific CMV antibody in the fractions suggested dissociation of IgG antibody from intermediate size complexes. Peak antibody levels found in the 12-14S areas of the neutral gradients shifted toward the lighter $7 \mathrm{~S}$ region after ultracentrifugation in acid gradients.

Single serum samples with high levels ( $\geq 1: 10)$ Raji cell reactivity collected from four infants with severe cytomegalic inclusion disease were similarly examined for evidence of immune complexes by ultracentrifugal analyses. To avoid heat inactivation, only the Raji cell assay was employed to assess fractions. In contrast to sera collected from infants with subclinical infection, Raji cell reactivity was found in the heavier, 18-22S fractions of the neutral gradients but similarly disappeared (three sera) or was markedly

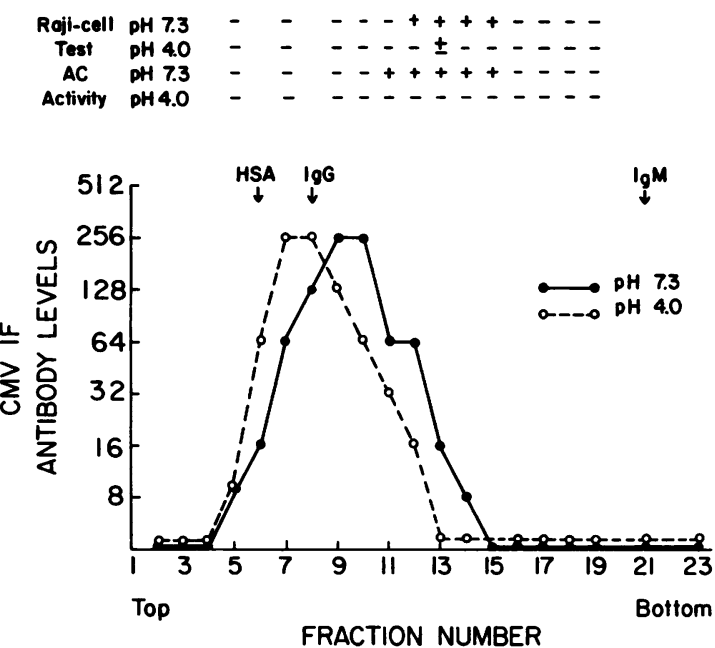

FIgURE 2 Acid dissociation of 135 immune complexes. Serum from an infant with subclinical CMV infection was fractionated in linear $10-30 \%$ sucrose density gradients prepared in Veronal-buffered saline, pH 7.3, and in acetate buffer, pH 4.0. Levels of IgG anti-CMV antibodies were determined by indirect IF. Shown at the top of the figure are the Raji cell test reactivity and the AC activity of fractions collected from both gradients. HSA, human serum albumin. diminished (one sera) after ultracentrifugation in acid gradients.

To better characterize the putative heavy complexes in sera obtained from sick infants, further purification and concentration steps were employed using one sample. The serum was first filtered through a Sephadex G-200 column. As shown in Fig. 3, after this separation, Raji cell reactivity was confined to fractions from the void volume of the column whereas CMV-specific antibody was present in fractions constituting the second and major protein peak containing IgG. Fractions 28-32 of the void volume containing Raji cell but lacking specific CMV antibody activity were pooled and concentrated 10 -fold by negative pressure. $0.2 \mathrm{ml}$ of the concentrate was then subjected to ultracentrifugal analyses in neutral and acid gradients. The results are shown

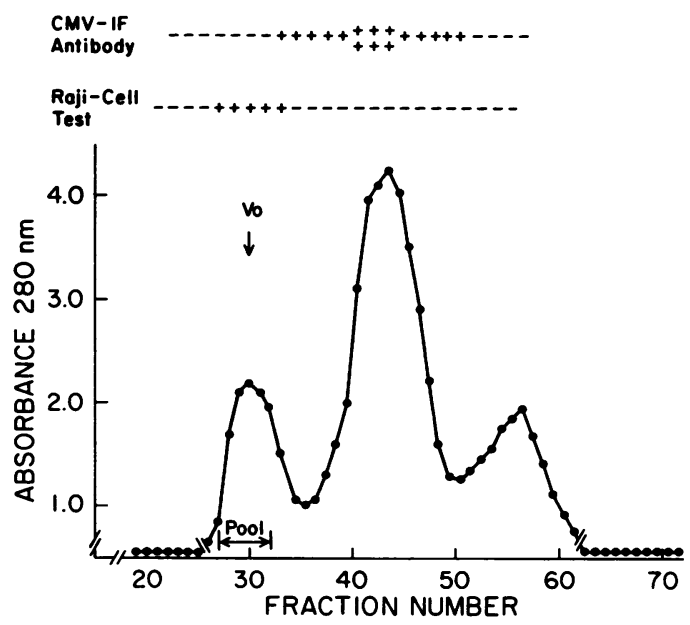

Figure 3 Gel filtration of a serum sample from a patient with symptomatic congenital CMV infection through a Sephadex G-200 column employing $0.1 \mathrm{M}$ Tris- $\mathrm{HCl}$ and $0.2 \mathrm{M}$ $\mathrm{NaCl}$ buffer, $\mathrm{pH} 8.0$, as eluant. The presence of immune complexes and IgG CMV antibodies on the different fractions was sought out by the Raji cell test and indirect IF, respectively. The six fractions containing immune complexes and lacking IgG CMV antibodies were pooled. Vo, void volume. 


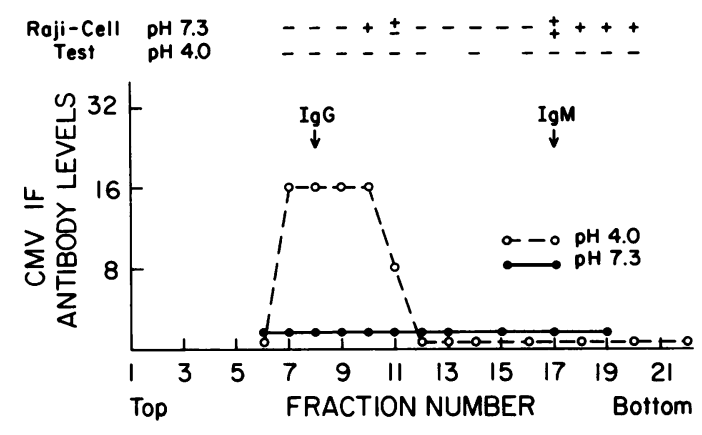

FIGURE 4 Acid dissociation of isolated 19S immune complexes. The pooled void volume of the Sephadex G-200 column shown in Fig. 3 was concentrated and subjected to ultracentrifugation in $10-40 \%$ gradient in Veronal-

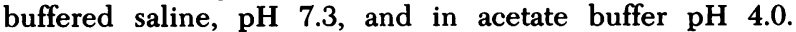
Levels of IgG anti-CMV antibodies were determined by indirect IF. Shown at the top of the figure is the Raji cell test reactivity with fractions collected from both gradients.

in Fig. 4. In fractions from the neutral gradient, Raji cell reactivity was again detected in the heavier, 18-22S fraction, as well as one in the intermediate, $10 \mathrm{~S}$ zone. CMV-specific antibody was not demonstrable in any of these fractions. With acid dissociation, Raji cell reactivity again disappeared. However, CMVspecific antibody activity was apparently unmasked and became detectable in the lighter IgG region of the gradient.

Immunohistopathology. As noted above, three infants with evidence of heavy complexes in their circulation died as a result of the severity of the CMV infection. Examination by indirect fluorescent microscopy of kidney sections from these three cases revealed glomerular deposits of IgG (Fig. 5), IgM, and C3 distributed in "lumpy-bumpy" patterns typical of immune complexes. After pretreatment of tissue sections with $2 \mathrm{M} \mathrm{NaCl}$ or $\mathrm{pH} 2.4$ glycine buffer for $30 \mathrm{~min}$, glomerular deposits of immunoglobulins and complement were no longer detectable. Attempts at demonstrating CMV antigens in similar location were not successful either before or after elution with similar buffers.

In an attempt to define further whether the immune deposits were filtered from the circulation and trapped in the glomeruli or whether they represented CMV antibody attached to infected cells, the distribution of viral cellular antigens in the kidney sections were sought employing the more sensitive ACIF assay. Specific fluorescent staining occurred primarily in the renal tubular cells (Fig. 6). There was a remarkable contrast between the very bright staining of the tubular cells and the faint granular fluorescence of the glomerular basal membrane (Fig. 6). Blocking with unconjugated anti-C3/C3c resulted in the suppression of fluorescence from both tubular epithelial cells and glomerular basal membrane, whereas the incubation of tissue sections with serum lacking CMV antibodies or heat inactivation of the complement source resulted in the disappearance of tubular fluorescence only. Thus, immune deposits in the glomeruli appeared to result from trapped antigen-antibody complexes rather than cell-fixed antibody and complement.

\section{DISCUSSION}

Virus antigen-antibody complexes occur frequently in many and perhaps most chronic viral infections of both animals and man, occasionally playing a prominent role in their pathogenesis (20). Immune complex disease is mediated by the deposition of antigen-antibody aggregates in tissue such as glomeruli, choroid plexus, and arterial walls. The basis

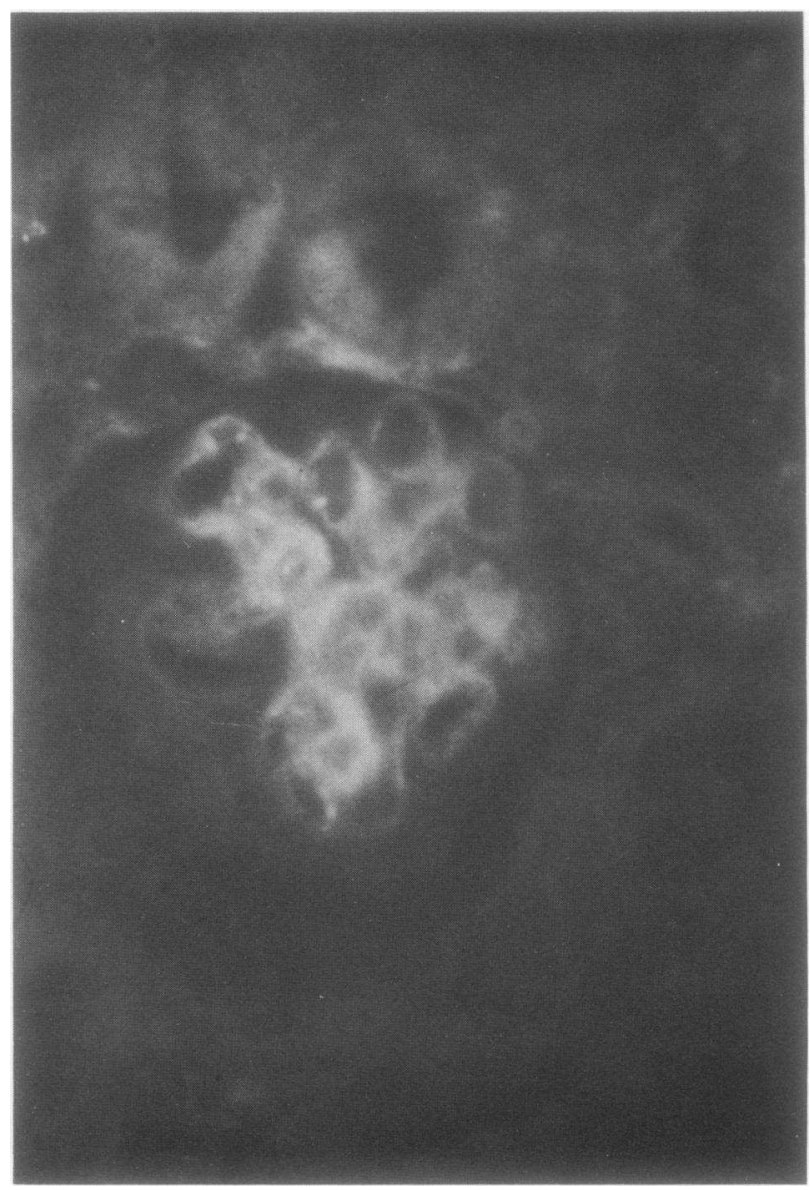

FIGURE 5 Photomicrograph of a renal glomerulus stained with fluorescein-conjugated antiserum to human IgG. Deposits of IgG are distributed along the glomerular basal membrane in a lumpy-bumpy pattern typical of immune complexes. After pretreatment of tissue sections for $30 \mathrm{~min}$ with $2 \mathrm{M} \mathrm{NaCl}$ or pH 2.4 glycine buffer, the IgG deposits became undetectable. 


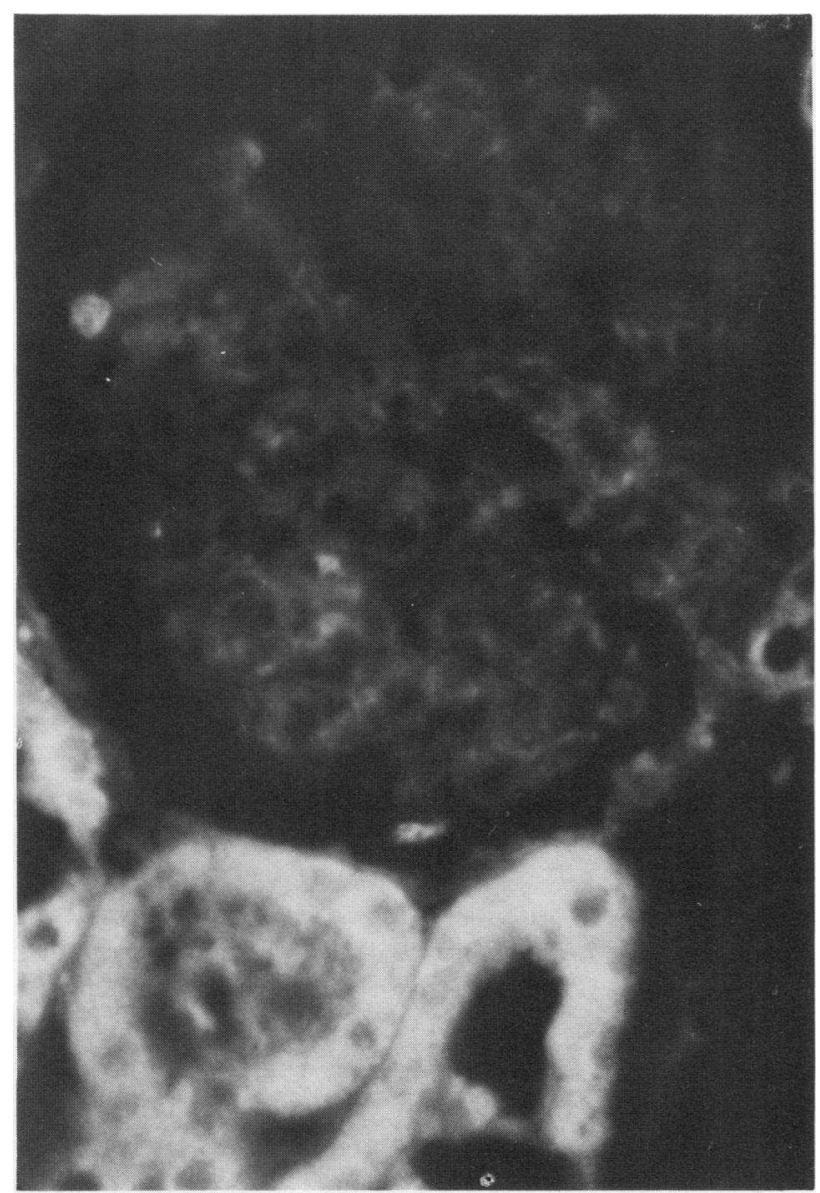

FIgURE 6 Photomicrograph of renal glomerulus and tubules stained for CMV antigens by the method of ACIF. The kidney section obtained from a fatal case of congenital CMV infection was mounted on a glass slide and incubated with heat-inactivated human serum. This serum had a 1:256 titer of complement-fixing antibodies to CMV and lacked antibodies to Epstein-Barr, varicella-zoster, and herpes simplex type II viruses. After $1 \mathrm{~h}$ at $37^{\circ} \mathrm{C}$, followed by thorough washing in phosphate-buffered saline, the tissue section was incubated for a similar period with a $1: 10$ dilution of fresh normal human serum lacking antibodies to CMV (complement source). The binding of C3 to viral antigen-antibody complexes was sought out with fluoresceinconjugated antiserum to human C3/C3c. Specific fluorescent staining is located primarily in the renal tubular cells. There is a remarkable difference between the very bright staining of tubular epithelium and the faint granular fluorescence of the glomerular basal membrane. Controls of specificity included incubation of similar tissue sections with serum lacking CMV antibodies, heat inactivation of the complement source, blocking with unconjugated antiserum to human $\mathrm{C} 3 / \mathrm{C} 3 \mathrm{c}$, and the use of kidney sections from uninfected infants who died of unrelated causes.

for the understanding of immune complex-mediated disease in perinatal infections has been provided recently by mouse models of lymphocytic choriomeningitis and murine-CMV infections (22-24).
As evidenced here, during the 1st yr after delivery, immune complexes apparently circulate in a significant proportion of infants congenitally infected by CMV and may occur with natal acquisition as well. Frequency increases with the severity of intrauterine infection. Within the very limited number of observations made thus far, the complexes appear to be heavier $(\geq 18-22 S)$ in sick, as opposed to asymptomatically infected, infants, in whom intermediate size complexes (12-16S) were found. Because of their larger size with severe disease, tissue deposition may occur as demonstrated in the renal glomeruli. Conclusions concerning frequency are based mainly in the high incidence of $\mathrm{AC}$ and Raji cell reactivity in sera of infected infants when compared to controls. One or both reactions occurred in two-thirds of all infants and one-third of all sera tested.

Exactly why antigen-antibody complexing should occur with greater facility during the lst yr after delivery in these persistent infections is unclear. However, indirect evidence using quantitative viral excretion from the urinary tract as a monitor of antigen production suggests a period in early life of relative antigen excess with intrauterine infection (6). During the first $6 \mathrm{mo}$, congenitally infected infants excrete significantly higher levels of virus than those natally infected, and sick infants consistently produce more virus than the asymptomatic ones. The humoral immune system is most markedly stimulated during this same period, irrespective of the nature of the congenital infection and continues to be long after levels of viral excretion among the different varieties of infection equalize (6-8). Thus, the patterns of viral production and humoral response parallel immune complex formation.

Inasmuch as no single laboratory procedure combines sensitivity, reproducibility, and specificity for detection and quantitation of circulating immune complexes, two complement-dependent tests were employed for assessments in this study. Correlation of results between $\mathrm{AC}$ and Raji cell reactivities was good but incomplete. 10 sera with insignificant AC activity reacted in the Raji cell test, and the reverse occurred with 6 sera. However, the reaction pathways of these two assays may differ. The Raji cell test detects IgG-containing complexes activating the complement system through either the classical or the alternative pathways. On the other hand, the complement fixation test, as performed here with a highly diluted source of complement, more likely detects classical pathway activating-complexes containing either IgG or IgM antibodies.

Certainly, factors other than immune complexes may react in the two assay systems producing false positive interpretations with regard to presence of immune complexes. Aggregated IgG, commonly 
found in stored sera, may activate the classical complement pathway causing AC activity. Bacterial proteases and other serum substances can also produce positive results. However, in this study, AC activity due to the presence of these substances should have been equivalent in control samples which were processed and stored in a similar manner to sera collected from the infected population. In addition, IgG aggregates, the most likely cause other than immune complexes for AC activity, are more resistant to acid dissociation than the active substances demonstrated here.

Concerning the specificity of the Raji cell assay for immune complexes, the presence of anti-bone marrow-derived (B) lymphocyte antibodies has recently been suggested at a cause for misinterpretation (25). They have been demonstrated only in diseased adults with systemic lupus erythematosus or rheumatoid arthritis and in normal pregnant women, especially the multiparous (26-28). Because these antibodies are mainly, if not exclusively, of the cold reactive IgM type, it is unlikely they caused false positive interpretations in this study, inasmuch as the test was performed at $37^{\circ} \mathrm{C}$ and IgM maternal antibody should not, if at all, be readily available in infant sera $(28,29)$. Warm reactive IgG anti-Blymphocyte antibodies could, however, cause confusion because, theoretically, they could be placentally transferred to the fetus, should they exist in the maternal circulation. $80 \%$ of the mothers of our study population were primiparous and therefore less prone to form lymphocyte antibodies which are stimulated primarily as a result of repeat pregnancies. In any event, such maternal antibodies should be found just as often in our control as in our infected infant population.

The possibility of anti-B-lymphocyte antibody production by the infant as a result of CMV infection has yet to be studied to our knowledge. Nevertheless, such an occurrence could not explain the excess AC activity seen in the infected population, and the concordance between this activity and positive Raji cell response make immune complex formation the most likely explanation for both.

The latter conclusion is further substantiated by the physiochemical characterization of the reactive substances in a few sera and immunologic studies of the kidney sections. The dissociation of reactive substances with acid treatment in sucrose gradients was followed in one case by recovery of 7S IgG antibodies with CMV specificity and, in two cases by significant shifts of antibody activity from intermediate to lighter zones of the gradients. In addition, in three out of four patients whose demise was due to severe congenital CMV infection, granular deposits of immunoglobulins and C3 were detected along the glomerular basal membrane of the kidney. Their distribution in a lumpy-bumpy pattern and their disappearance after acid treatment was typical of immune complexes. All four infants had 19-20S acid-dissociable complement-binding substances in their serum. Although we could not demonstrate CMV antigens in this location, we believe that these immune substances were trapped from the circulation and did not represent CMV antibodies attached to local infected cells. This contention is supported by the selective distribution of CMV antigens in the tubular epithelium documented here and previously by others by the ACIF assay (16). The presence of large quantities of CMV antigen and cellbound antibody in the tubular elements complicates the use of elution experiments to designate immune complex specificity of CMV antibody in the glomeruli.

Virus antigen-antibody complexes are known to have pathologic potentials largely dependent upon the quantitative relationships of their two reactants (30). Complexes formed in slight antigen excess are large $(>19 S)$, like those shown here in sick neonates and may lead to tissue injury by deposition in the glomeruli, choroid plexus, and blood vessels. Their accumulation at these sites occurs when the rate of deposition exceeds that of degradation and elimination. Whether this immunologically mediated mechanism contributes to the adverse clinical course of the severe and fatal cases with congenital CMV infection remains unresolved. In the past, little attention has been given to renal function because of the more obvious and hazardous involvement of the reticuloendothelial and central nervous systems. In fact, immune complexes might be even contributory to the pathology in these organ systems in fulminant infections. With subclinical infections signs or symptoms of immune complex disease, such as those seen in serum sickness, rheumatoid arthritis or systemic lupus erythematosus have not been encountered. Instead, mental deficiency and sensorineural hearing loss are more prominent along with persistence of virus excretion, measured in years $(5$, 31). Conceivably, circulating immune complexes could contribute to this insidious, progressive organ disease by interfering with host defense mechanism or by direct tissue damage in concert with continued low level viral replication. Because of the high incidence of perinatal CMV infection, precise definition of pathogenetic mechanisms is mandatory to design more effective therapeutic measures than those currently being attempted.

\section{ACKNOWLEDGMENTS}

This work was supported by research grant RO1 HD01687 and training grant TO1 HD00413 from the National Institute of Child Health and Human Development, Clinical Research Center grant 5 MO1 RR32 from the National Institutes 
of Health, contract NO1 CB 53893 from the National Cancer Institute, March of Dimes grant 6-27 from the National Foundation, and a grant from The Meyer Foundation.

\section{REFERENCES}

1. Hanshaw, J. B. 1971. Congenital cytomegalovirus infection: a fifteen year perspective. J. Infect. Dis. 123: $555-561$.

2. Stern, H., and S. M. Tucker. 1973. Prospective study of cytomegalovirus infection in pregnancy. $\mathrm{Br}$. Med. J. 2: 268. (Abstr.)

3. Stagno, S., D. W. Reynolds, E. S. Huang, S. D. Thames, R. J. Smith, and C. A. Alford, Jr. 1976. Congenital cytomegalovirus infection: occurrence in an immune population. N. Engl. J. Med. 296: 1254-1258.

4. Reynolds, D. W., S. Stagno, T. S. Hosty, M. Tiller, and C. A. Alford. 1973. Maternal cytomegalovirus excretion and perinatal infection. N. Engl. J. Med. 289: 1-5.

5. Alford, C. A., S. Stagno, D. W. Reynolds, A. Dahle, C. Amos, and S. Saxon. 1976. Long-term mental and perceptual defects associated with silent intrauterine infections. In Intrauterine Asphyxia and the Developing Fetal Brain. L. Gluck, editor. Year Book Medical Publishers, Inc., Chicago. In press.

6. Stagno, S., D. W. Reynolds, A. Tsiantos, D. A. Fuccillo, W. Long, and C. A. Alford. 1975. Comparative serial virologic and serologic studies of symptomatic and subclinical congenitally and natally acquired cytomegalovirus infections. J. Infect. Dis. 132: 568-577.

7. Reynolds, D. W., S. Stagno, K. G. Stubbs, A. J. Dahle, M. M. Livingston, S. S. Saxon, and C. A. Alford. 1974. Inapparent congenital cytomegalovirus infection with elevated cord IgM levels. N. Engl. J. Med. 290: 291-296.

8. Stagno, S., J. E. Volanakis, D. W. Reynolds, R. Stroud, and C. A. Alford. 1977. Virus-host interactions in perinatally acquired cytomegalovirus infections of man: comparative studies on antigenic load and immune complex formation. In The Development of Host Defenses. M. D. Cooper and D. H. Dayton, editors. Raven Press, New York. 237-250.

9. Stagno, S., J. E. Volanakis, R. Stroud, and C. A. Alford. 1977. Detection of immune complexes in perinatally acquired cytomegalovirus infections by complement dependent assays. In Clinical Aspects of the Complement System. W. Opferkuch and K. Rother, editors. Georg Thieme Verlag KG. Stuttgart. In press.

10. Wasserman, E., and L. Levine. 1961. Quantitative microcomplement fixation and its use in the study of antigenic structure by specific antigen-antibody inhibition. J. Immunol. 87: 290-295.

11. Theofilopoulos, A. N., C. B. Wilson, V. A. Bokisch, and F. J. Dixon. 1974. Binding of soluble immune complexes to human lymphoblastoid cells. II. Use of Raji cells to detect circulating immune complexes in animal and human sera. J. Exp. Med. 140: 1230-1244.

12. Lowry, O. H., N. J. Rosebrough, A. L. Farr, and R. J. Randall. 1951. Protein measurement with the Folin phenol reagent. J. Biol. Chem. 193: 265-275.

13. Mancini, G., A. O. Carbonara, and J. G. Heremans. 1965. Immunochemical quantitation of antigens by single radial immunodiffusion. Immunochemistry. 2: 235-254.

14. Scheidegger, J. J. 1955. Une micro-méthode de l'immunoélectrophorèse. Int. Arch. Allergy Appl. Immunol. 7: 103-110.

15. Sainte-Marie, G. 1962. A paraffin embedding technique for studies employing immunofluorescence.J. Histochem. Cytochem. 10: 250-256.

16. Huang, E. S., B. A. Kilpatrick, Y. T. Huang, and J. S. Pagano. 1976. Detection of human cytomegalovirus and analysis of strain variation. Yale J. Biol. Med. 49: 29. (Abstr.)

17. Cooper, M. D., A. R. Lawton, and D. W. Bockman. 1971. Agammaglobulinaemia with b lymphocytes specific defect of plasma cell differentiation. Lancet II: 791-795.

18. Koffler D., P. H. Schur, and H. G. Kunkel. 1967. Immunological studies concerning the nephritis of systemic lupus erythematosus. J. Exp. Med. 126: 607-631.

19. Henle, G., and W. Henle. 1966. Immunofluorescence in cells derived from Burkitt's lymphoma. J. Bacteriol. 91: 1248-1256.

20. Schmidt, N. J., E. H. Lennette, J. D. Woodie, and H. H. Ho. 1965. Immunofluorescent staining in the laboratory diagnosis of varicella-zoster virus infections. $J$. Lab. Clin. Med. 66: 403-412.

21. Reedman, B. M., and B. Klein. 1973. Cellular localization of an Epstein-Barr virus (EBV) associated complement-fixing antigen in producer and non-producer lymphoblastoid cell lives: EBV-associated nuclear antigen. Int. J. Cancer. 11: 499-520.

22. Oldstone, M. B. A. 1975. Virus neutralization and virusinduced immune complex disease. Prog. Med. Virol. 19: 84-119.

23. Oldstone, M. B. A., and F. J. Dixon. 1969. Pathogenesis of chronic disease associated with persistent lymphocytic choriomeningitis viral infection. I. Relationship of antibody production to disease in neonatally infected mice. J. Exp. Med. 129: 483-505.

24. Olding, L. B., D. T. Kingsbury, and M. B. A. Oldstone. 1976. Pathogenesis of cytomegalovirus infection. Distribution of viral products, immune complexes and autoimmunity during latent murine infection. J. Gen. Virol. 33: 267-280.

25. Williams, R. C., Jr., A. D. Bankhurst, and J. D. Montano. 1976. IgG antilymphocyte antibodies in SLE detected by ${ }^{125}$ I protein A. Arthritis Rheum. 19: 1261-1270.

26. Stastny, P., and M. Ziff. 1971. Antibodies against cell membrane constituents in systemic lupus erythematosus and related diseases. Clin. Exp. Immunol. 8: 543-550.

27. Winfield, J. B., R. J. Winchester, P. Wernet, S. M. Fu, and H. G. Kunkel. 1975. Nature of cold reactive antibodies to lymphocyte surface determinants in systemic lupus erythematosus. Arthritis Rheum. 18: 1-8.

28. Winchester, R. J., S. M. Fu, P. Wernet, H. G. Kunkel, B. Dupont, and C. Jersild. 1975. Recognition by pregnancy serums of non-HL-A alloantigens selectively expressed on B lymphocytes. J. Exp. Med. 141: 924-929.

29. Theofilopoulos, A. N., and F. J. Dixon. 1976. Complement receptors on Raji cells as in vitro detectors of immune complexes in human sera. In Manual of Clinical Immunology. N. R. Rosen and H. Frieman, editors. American Society for Microbiology, Washington, D. C. 676-681.

30. Oldstone, M. B. A., and F. J. Dixon. 1971. Immune complex disease in chronic viral infections. J. Exp. Med. 134: 325-405.

31. Stagno, S., D. W. Reynolds, C. S. Amos, A. J. Dahle, F. P. McCollister, I. Mohindra, R. Ermocilla, and C. A. Alford. 1977. Auditory and visual defects resulting from symptomatic and subclinical congenital cytomegaloviral and Toxoplasma infections. Pediatrics. 59: 669-678. 